\title{
Language Policy of a Nation: Literature review in Language Planning Models and Strategies: A Brief Overview
}

\author{
Dr. Niruba Sarath Jayasundara \\ Senior Lecturer in Linguistics, Department of Languages and Communication Studies, \\ Trincomalee Campus, Eastern University Sri Lanka \\ Email: niruba2371@gmail.com \\ DOI: $10.31364 /$ SCIRJ/v9.i02.2021.P0221842 \\ http://dx.doi.org/10.31364/SCIRJ/v9.i02.2021.P0221842
}

\begin{abstract}
This Paper aims at briefing the different models of language planning activities which strategically targets a language policy of any nation. It begins with introducing the term of Language planning and policy in the literature of Linguistics and moves on describing the steps/ stages adopted in Language planning strategy. Apart from the stages the positive and negative planning implemented in nations are briefed. The outcome and challenges of implementation of the models of language planning is discussed and finally, it ended up with how the nations adopted national language policy, official language policy and medium of instructions policy by implementing the strategies of language planning.
\end{abstract}

Key words: language planning, language policy, three-level language planning, integrated language planning, system thinking approach

\section{Introduction}

Language planning was first put forward by Uriel Weinrich, in 1957, at a seminar held in Columbia University, the U.S. In the literature concerned with "language planning" the American-Norwegian sociolinguist Einar Haugen is often mentioned as the person who gave birth to the concept. In the article "Language Planning in Modern Norway "(1959), which was widely acknowledged after its second edition in 1968, Haugen introduced and attempted to define the concept. Einar Haugen's View of Language planning is a technocratic process concerned with systematizing and cultivating a standardized language code to solve problems. "the development of policies or programs designed to direct or change language use, as through the establishment of an official language, the standardization or modernization of a language, or the development or alteration of a writing system". http://dictionary.reference.com/. "The numerous attempts that have been made to change a particular variety of a language, or a particular language, or some aspect of how either of these functions in society. Such changes are usually described as instances of language planning" Ronald (1998, p. 347) "Language planning is a government authorized, long term, sustained, and conscious effort www.scirj.org 
to alter a language's function in a society for the purpose of solving communication problems" Weinstein (1980, p. 56) "Language planning involves the creation and implementation of an official policy about how the languages and linguistic varieties of a country are to be used." David Crystal (1996, p. 366). American linguist Joshua Fishman has defined language planning as "the authoritative allocation of resources to the attainment of language status and corpus goals, whether in connection with new functions that are aspired to or in connection with old functions that need to be discharged more adequately" (1987). Cooper (1989) defines language planning as" deliberate efforts to influence the behavior of others with respect to the acquisition, structure, or functional allocation of their language codes" (p. 45).

Different social groups wish to maintain their linguistic identities and interests, and may actively and often violently campaign for recognition. Changes increasing, countries becoming aware, it is not possible to rely on the slow course of natural linguistic evolution to resolve the pressures and conflicts that arise. Therefore, many governments try to solve their problems by engaging in conscious, principled 'language planning', or 'linguistic engineering'. Language planning is carried out by government departments and agencies, language academies, committees, popular societies, however, newspapers or broadcast media, publishing houses, political groups, community agencies, and religious centers may also be important language planning agents.

Language planning is that area which is the overlap between the applied and socio-linguistics. This is referred to that area which the researcher aims at identifying and this activity results in exerting a large amount of influence over the prevalence of any language. The main three areas that are most talked in case of language planning includes- status, corpus and acquisition. However there exists very less information on the need for language planning. One vital need for language planning arises when the prevalence of one particular group of language users in a diverse language community is greater or less than desired so the language planning can be undertaken which can change the prevalence towards any desired goal (Milligan, 2007).

\section{Steps in Language Planning}

According to Haugen (1983) a language plan is a strategy based on a particular model. The Haugen's (1983) model of language planning sets out leading elements similar to planning of language that support to begin a specific policy of language. The Haugen language planning model includes four basic stages namely selection, codification, implementation and elaboration. The selection step includes the option of a language or different languages as official or national languages. Hassan (2004) has mentioned the next step codification necessitates selection of norms and it gives a written form to norm chosen. It targets at selected language standardization.

Codification and selection remain major theories unless followed by elaboration and implementation. The implementation includes the writer, civil institutions and government agencies activities in utilizing and adopting the preferred form of language. Finally, the

$$
\text { WwW.scirj.org }
$$

(C) 2021, Scientific Research Journal

http://dx.doi.org/10.31364/SCIRJ/v9.i02.2021.P0221842

This publication is licensed under Creative Commons Attribution CC BY. 
elaboration step includes the language functions expansion to attain the modern world requirements such as assignment of new technological and scientific terms to language.

\section{Positive and Negative Language Planning}

Language planning can be either positive or negative in nature. Positive language planning is a term which is used at the time when language planning activity leads to increase or sustainability of any language. We can include here the examples of nation-states which are presently engaging in a positive language planning which includes Ireland and Canada. Also, positive language planning is used to denote the term reversing language which occurs and focuses on those languages which have lost their present vitality. The main aim of positive language planning is to keep a minority or endangered language from becoming extinct but can also be conducted for other languages too to make it stronger.

On the other hand, negative language planning is a term that is used to identify any language planning activity that aims at decreasing the strength of language. Some of the examples of countries which have engaged negative language planning are United Kingdom and Canada. The negative language planning is often regarded as suppression of minority languages by a majority group of language. However, it must be noted here that negative language planning can also be enacted with the help of positive language planning which in turn can help to secure and strengthen the minority language and weaken the majority language (Milligan, 2007).

\section{Different models of Language Planning}

According to Donnacha (2000) two new language planning models are suggested in this study. The approach is common to that utilized in business planning of viewing organizations and industries as sets of interrelated tasks as a support to planning and analysis. The first model evolves a three-level language planning view and targets to evolve a much strategic approach. In this model the three levels are Language planning, functional language planning and status planning. The second model is integrated language planning model is associated to language planning's second level and is configured to facilitate an integrated and comprehensive approach to strengthen targeted languages. The model disaggregates efforts of language reinforcement into two kinds of activities namely support and primary activities. The support activities assist the primary activities and each other by facilitating and managing the effort of language reinforcement whereas the primary activities are those that are configured to impact changes directly in behavior of language. According to Milligan (2007) system thinking is a way of thinking about social, biological and other phenomena that places steady emphasis on rapport between variables.

A system thinking approach to language planning has not been included into language planning but facilitates the making of a cumulative and comprehensive model of negative and positive language planning. In other words, the system thinking approach to

WwW.scirj.org

(C) 2021, Scientific Research Journal

http://dx.doi.org/10.31364/SCIRJ/v9.i02.2021.P0221842

This publication is licensed under Creative Commons Attribution CC BY. 
language planning has permitted the making of system model of language planning because it is a methodology that holds external impacts. The system model of language planning integrates the traditional tripartite language planning activity structure and describes both negative and positive initiatives of language planning. The model decides the requirement for negative or positive activities of language planning by tallying disparity between desired and actual population of language users within a different community of language. The impact of language planning activity on abandonment and acquisition must evaluate intermediary variables namely cultural functions, resources of learning, economic functions, corpus functions and/or political functions. The language planning activities success as described in this model is evaluated by supervising the degree to which interventions targeted at managing abandonment or acquisition have impacted the language users' actual population.

\section{Effectiveness of using different models of language planning strategies in deciding the medium of instruction, national} language and official language

According to Swann et al (2004) language planning is considered widely as an overlap area between sociolinguistics and applied linguistics. It is a study area in which researcher seeks to recognize activity that would exert impact over the language prevalence. When one set of language users' prevalence in a different community of language is lesser or greater than desired language planning can be carried out to change this prevalence towards a stipulated target.

According to Liddicoat (2008) integrated language planning offers chances for students to gain a new language through discipline based learning domain study such as mathematics, arts, science and humanities. The approaches of language instruction that integrate language and content are probable to be much efficient than approaches in which language is taught in isolation. Haugen language planning model proved to be powerful and has supported several studies in various kinds of the globe (Swann et al, 2004 and Liddicoat, 2008).

Jernudd and Gupta (1971) quoted that language planning can outcome in offering numerous advantages to society. Firstly, it offers some extent of linguistic homogeneity it can permit for better and rapid interaction and consequent development in the living standard. Second language planning is so far as it offers a common way of communication can outcome in involvement's greater equalities. According to Lee et al (1992) the language planning may prove to be effective if it is implemented properly and it can offer chances to entire people to have common political and economic power but if it is against its spirit it may lead to severe consequences such as language riot, power struggle and language movements. Language planning also promotes the use of specific language it can enhance national consciousness sense thus strengthening the country's political unity (Lee et al, 1992 and Fishman eds, 1993).

WwW.scirj.org

(C) 2021, Scientific Research Journal

http://dx.doi.org/10.31364/SCIRJ/v9.i02.2021.P0221842

This publication is licensed under Creative Commons Attribution CC BY. 
Sterman (2000) has mentioned that system thinking provides a strong new perspective, a set of components and a specialized language which an individual can utilize to mention the most stubborn issues in her or his everyday work and life. The system thinking approach to language planning motivates the language study perceiving that its status, acquisition and corpus are interlinked. Systems thinking permits to acquire a better understanding of language planning complexities by making a visual model reflecting the interlinks among and within language vitality aspects (Lee et al, 1992).

Fishman eds (1993) has described that there are two advantages to bring system thinking approach to theory of language planning. First this approach permits for incorporation and assimilation of principles and hypotheses from forerunners of the field into an individual qualitative language planning model that utilizes archaic graphical language. Harmann (1990) has pointed out second advantage of system thinking approach as that it permits for making of a language planning model that is applicable broadly and flexible. System thinking can negate placing any language vitality area in privilege position by recommending that every area in which functions of language is one kind of meta-system. Thus, it can be inferred that for language planning to be effective the big term viability of community expected to assist the language has to be considered (Harmann, 1990 and Lee et al, 1992).

According to Kaplan and Baldauf (2011) and Meinhof and Makoni (2004) selecting a group of languages or specific language for particular functions in nation has far reaching suggestions on the status of group of languages or language (Meinhof and Makoni, 2004). Coperahewa (2011) have stated that moreover, selection has several suggestions for educational institutions and economies of promoting a language. Each and every language has to be taught for specific aim or there must be no justification for material, human and financial resources expanded on teaching a particular language for its sake (Hamid, 2010 and Kaplan and Baldauf, 2011). Kaplan and Baldauf (2011) have pointed out five main reasons for language planning considered as political activity would fail. According to Hamid (2010), extra languages are reached through educational institutions that include a restricted research, for example if we consider Indonesia, it could take 5 or 6 school leavers generations prior the national language is famous. Apart from these, education competes for investing against certain priorities like external and internal as well as educational institutions are much slower to respond to modification in areas like textbooks, curricula, teacher training and attitudes. Successfully spreading language required to be society-based and going beyond education.

Language planning would take tough selections about which language to decide and support for example in South Africa has twelve national languages and selections would be tough to agree upon (Meinhof and Makoni, 2004). Challenges such as religion would make selection of language problematic for example, the present separation of Sudan like Arabic and Islam and South Sudan such as English and Christianity (Abdelhay, Makoni and Makoni, 2013). Hsiau (1997) stated that other challenges such as political beliefs in Taiwan such as Mandarin and Taiwanese or foreign alliances in Vietnam like English versus Russian (Wright, 2002) would dominate

Www.scirj.org

(C) 2021, Scientific Research Journal

http://dx.doi.org/10.31364/SCIRJ/v9.i02.2021.P0221842

This publication is licensed under Creative Commons Attribution CC BY. 
choices of policy (Chua, 2012). In some cases, particularly with centralized systems, facilitating language programs logistics would be issue and does not consider variances in different regions of the nation. When we consider Brunei and Malaysia, Martin (2005) have stated that other than local materials that are being built for teaching English were not appropriate for some more isolated regions of nation. Hamid and Baldauf (2011) had pointed out that the situations in Bangladesh differ from the Dhaka and other rural areas and it would be tough to adopt a unitary curriculum. Kaplan and Baldauf (2011) mentioned that some questions arise what must be taught namely dialect, macro skill focus, methodology and orthography to be used. Teachers' qualifications would also be problematic. Some questions would be raise like which characters in the Chinese language has to be used such as traditional or simplified? Are Chinese characters being subsection of language in Korea or must they be eliminated? (Hamid and Baldauf, 2011 and Kaplan and Baldauf, 2011); Whether Korean be purified characters as seen in North Korea wherein foreign language are taught as characters. Whether communication language teaching is suitable methodology in contexts of Confucian teaching? What kind of training do different levels of teachers of English need? Whether the fundamental teaching purpose to assist student for passing examinations? What types of English must be taught such as Australian, American, Canadian, South Asian and British? (Kaplan and Baldauf, 2011). According to Coperahewa (2011) the languages to be taught would in problem as when we consider Sri Lanka wherein the prolonged war for civil would be fueled by disputes of policies over the status of Tamil and Sinhala that is the language rights denial to Tamils or by issues already mentioned in the Sudan (Coperahewa, 2011 and Balsing, 2013).

We will look at a variety of linguistic situations in the world to see some instances of planning. France serves as a good example of a country which has a single national language and does little or nothing for any other language. The bilingualism of Belgium. Today, French and Flemish(Dutch) co-exist in a somewhat uneasy truce in Belgium. The struggle between the French and the Flemish has a long history.

Not all countries have codified national language policies, and when they do the subjects that covered vary from one country to another. They also differ immensely in the centralization of planning and control, ranging from the dominance of planning at the national level in Japan and Netherlands, to the locus of language policy making at the state and canton level in Germany and Switzerland, to the completely decentralized language policymaking in the United States.

\section{Conclusion}

"A good deal of language planning after the Second World War was undertaken by emerging nations that arose out of the end of colonial empires. These nations faced decisions as to what language(s) to designate as an official for use in the political and social arena. Such language planning was often closely aligned with the desire of new nations to symbolize their newfound identity by

$$
\text { WWW.scirj.org }
$$

(C) 2021, Scientific Research Journal

http://dx.doi.org/10.31364/SCIRJ/v9.i02.2021.P0221842

This publication is licensed under Creative Commons Attribution CC BY. 
giving official status to the indigenous language(s)" (Kaplan, 1990, p. 4). Today, however, language planning has a somewhat different function. A global economy, growing poverty in some nations of the world, and wars with their resulting refugee population have resulted in great linguistic diversity in many countries. Thus, language planning issues today often revolve around attempts to balance the language diversity that exists within a nation's borders caused by immigration rather than by colonization.

\section{References}

1. Balsing.L (2013), Making English the Lychpin for Globalization of education in Sri Lanka: Quality Versus Equality, ECU.

2. Chua, S. K. C. (2012). Singapore ees E(Si)nglish-knowing bilingualism. In R. B. Baldauf Jr., R. B. Kaplan, N. M. Kamwangamalu, and P. Bryant (Eds.), Language planning in primary schools in Asia (pp. 21-41). New York/London: Routledge

3. Cobarrubius, Juan and Fishman J, eds. Progress in Language Planning: International Perspective. The Hague: Mouton, 1993.

4. Cooper, R. (1989). Language planning and social change. Cambridge Cambridge University Press.

5. Coperahewa, S. (2011). The language planning situation in Sri Lanka. In R. B. Kaplan and R. B. Baldauf Jr. (Eds.), Language planning in the Asia Pacific: Hong Kong, Timor-Leste and Sri Lanka (pp. 160-241). London/New York: Routledge

6. Haarmann, H. (1990) Language planning in the light of a general theory of language:A methodological framework. International Journal of the Sociology of Language 86, 103-126

7. Hamid, M. O. (2010). Globalisation, English for everyone and English teacher capacity: Language policy discourses and realities in Bangladesh. Current Issues in Language Planning, 11(4), 289-310

8. Haugen, E. (1983). The implementation of corpus planning Theory and practice. In Cobarrubias, J. Fishman, J.A. (eds.). Progress in language planning. Berlin Mouton, 269-289.

9. Hsiau, A-C. (1997). Language ideology in Taiwan: The KMT ${ }^{e e}$ s language policy, the Tai-yu language movement, and ethnic politics. Journal of Multilingual and Multicultural Development, 18(4), 302-315.

10. Jernudd.B.H and Gupta.D (1971), Towards a Theory of Language Planning, Can Language be Planned? J.Rubin and B.H Jernudd (eds), 195-215. Hawaii: East-West Center/the University Press.

11. Joshua A. Fishman, (1972)"The Impact of Nationalism on Language Planning," 1971. Rpt. in Language in Sociocultural Change: Essays by Joshua A. Fishman. Stanford University Press,

12. Kaplan, R. B., and Baldauf, R. B. Jr. (2011). The politics of language planning: Why doesn "et language planning always work? Paper presented at the 3rd Language, Education and Diversity Conference, Auckland, N.Z., November 22-25.

13. Kaplan, R. B. Baldauf, R. B. 1997. Language planning From practice to theory. Clevedon, England Multilingual Matters Ltd.

14. Liddicoat, J (2008), Models of National Government Language-in-education Policy for Indigenous Minority Language Groups, Retrieved On:16th Oct 2014, Retrieved From: http://www.als.asn.au/proceedings/ als2007/liddicoat.pdf

15. McKay, Sandra Lee and Wong, Sau-ling Cynthia (eds.) (1992). Language Diverstiy: Problem or Resource? New york: Newbury House, 29-68.

16. Makoni, S., and Meinhof, U. H. (2004). Western perspectives in applied linguistics in Africa. AILA Review, 17(1), 77-104

17. Sterman.J.D (2000), Business Dynamics, Systems Thinking and Modelling for a Complex World, Irwin McGraw Hill, Boston.

18. Swann. J, Deumert. A, Lillis.Tand Mesthrie. R, 2004, A Dictionary of Sociolinguistics, Edinburgh, Edinburgh University Press.

19. Wright, S. (2002). Language education and foreign relations in Vietnam. In J. W. Tollefson (Ed.), Language policies in education: Critical issues (pp. 225-244). Mahwah, N.J.: Lawrence Erlbaum

Www.scirj.org

(C) 2021, Scientific Research Journal

http://dx.doi.org/10.31364/SCIRJ/v9.i02.2021.P0221842

This publication is licensed under Creative Commons Attribution CC BY. 


\section{Author}

First Author - Dr.Niruba Sarath Jayasundara Senior Lecturer in Linguistics, Department of Languages and Communication Studies, Trincomalee Campus, Eastern University Sri Lanka. niruba2371@gmail.com 